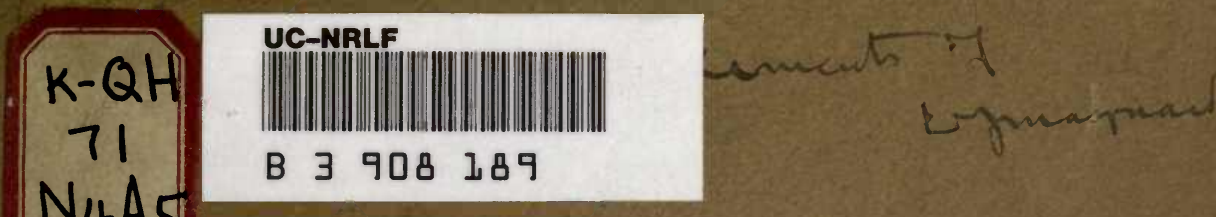

$\mathrm{N}_{4} \mathrm{As}$

ANNOTATED

OATAIOGUH

OF THE COLLECTIONS

OF THE

MAYNARD CHAPTER

OF THE

NEWTON NATURAL HISTORY SOCIETY

ILLUSTRATED

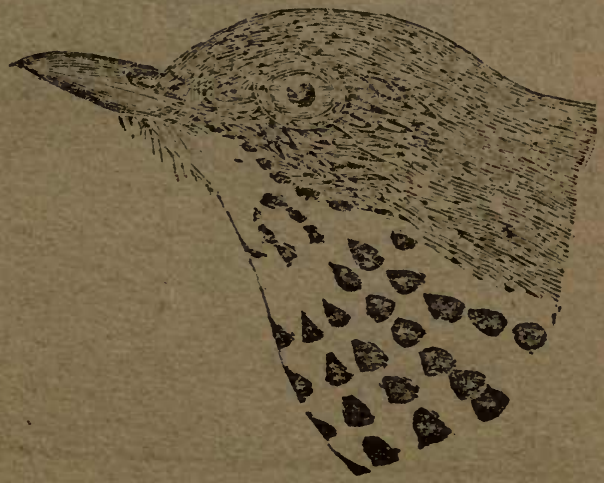

Elosd of Wood Thruleh.

WEST NEWTON

C. J. MAYNARD 


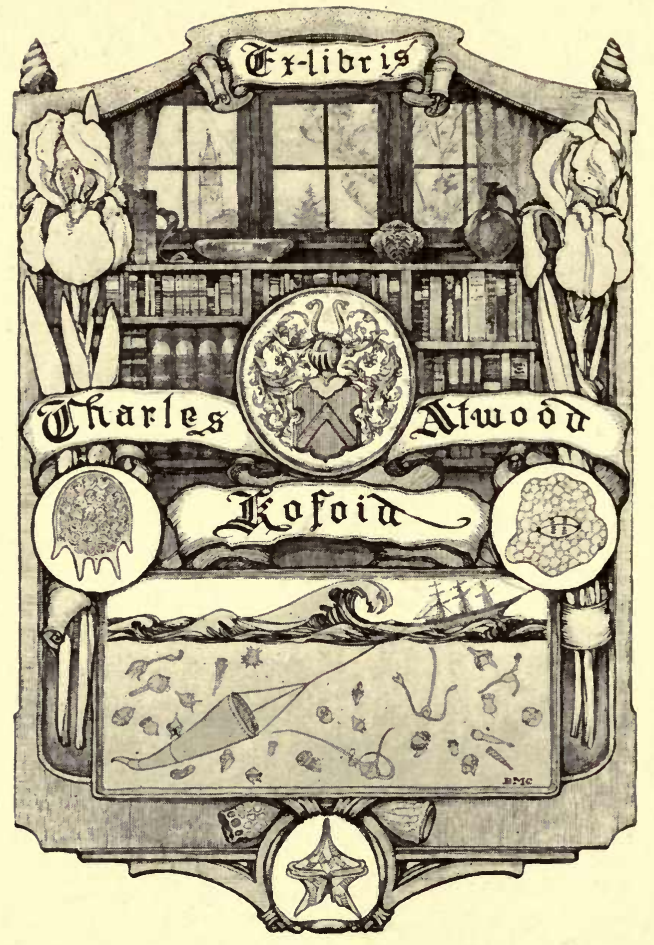




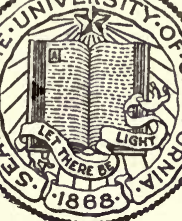

THE LIBRARY $\mathrm{OF}$ THE UNIVERSITY OF CALIFORNIA

PRESENTED BY PROF. CHARLES A. KOFOID AND MRS. PRUDENCE W. KOFOID 

OATAIOGUH

\section{OF THE COLLECTIONS}

OF THE

\section{MAYNARD CHAPTER}

OF THE

NEWTON NATURAL HISTORY SOCIETY

I L L USTRATED

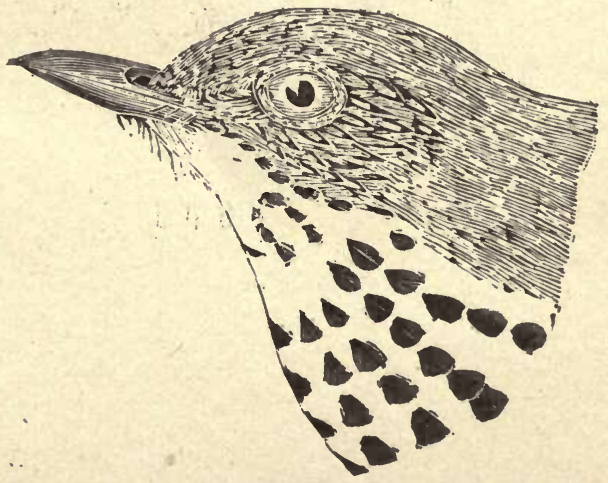

Hoad of Wood Thrush.

W EST N E W T O N

C. J. MAYNARD

1903 


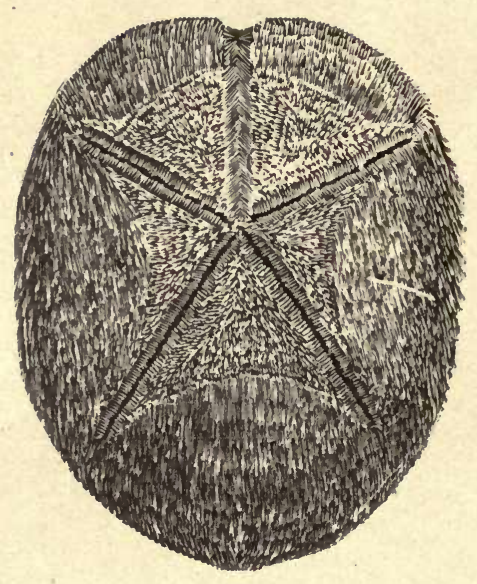

$\therefore \quad \therefore 10$ 


\section{DEDICATED}

TO

Jigse F. Frisbie M. D.

FOUNDER OF THE

Newton Natural History Society

AND FOR MANY YEARS ITS PRESIDENT

IN GRATEFUL ACKNOWLEDGEMENT

OF THE MANY SERVICES

HE HAS RENDEREED

THE SOCIETY 


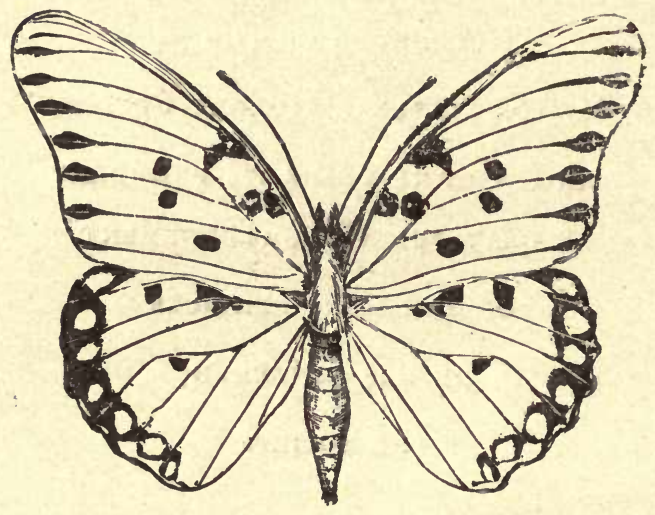




\section{PROSPECTUS.}

The accompanying sheets contain the title, introduction and sample pages of the catalogue of the collection of the Maynard Chapter. This catalogue is now ready for distribution to the subscribers. As will be seen upon examination of the pages, this is rather more than a catalogue, as considerable information in regard to the specimens is printed; this information is intended as a guide to students in their studies. The specimens catalogued, unless otherwise stated, are for free distribution to members of the chapter who own catalogues, and to other responsible persons, even if they reside at a distance, who purchase a catalogue and a card. The price of the catalogue is $25 \mathrm{cts}$ each to all; cards are free to members, but their price to others is ro cts. each. Each card entitles the holder to fifty specimens, of which five may be borrowed at one time and kept for a week, then, in some cases, if desired, renewed for another week. Bird skins and other light specimens may be sent out and returned by mail at the rate of one cen per ounce, or to clubs of several individuals, as cheaply, or cheaper by express, always at the expense of the borrower.

As it is desirable for the publisher of the catalogue to know how many copies it is best to print, those who desire to avail themselves of the opportunity afforded to borrow bird skins, minerals, etc., should apply at once to the publisher for catalogues.

As this catalogue is to be circulated largely among teachers, to be permanently kept, the attention of professional men and others, who hope for the patronage of teachers, is called to it as an excellent advertising medium.

All money received in excess of the cost of the catalogue will be expended, at least at present, in the purchase of additional bird skins.

For catalogues apply to C. J. Maynard, 447 Crafts st. and for advertising space to him and to E. F. Dow, 6I Henshaw st., both West Newton, Mass. 
$\mathrm{Cn}$ the evening of October 21,1879 , several gentlemen met at the house of Dr. J. F. Frisbie in Newton, at his suggestion, for the purpose of organizing a society for the study of natural history. On October 29 the Newton Natural History Society was formally organized at the house of the Rev. G. W. Shinn. This society at once became-popular, and on Feburary 26,1883 , was incorporated with a membership of over one hundred.

For a number of years the meetings of the society were well attended, and many valuable papers were given before it by specialists and scientists. Some of these papers were printed, and in $1889-90$ the society issued a monthly Bulletin of its proceedings.

For reasons which are difficult to understand, shortly after 1892 public interest in the society gradually waned, and its membership decreased, until finally the meetings were held at wide and irregular intervals. Early in I899 Mr. C. J. Maynard proposed to organize a branch of the society in order to render especial assistance to the teachers and pupils of New. ton and neighboring towns, as well as others who had a liking for nature study.

A well attended meeting was held at Mr. Maynard's laboratory on May 6, I 899 and the Maynard Chapter of the New. ton Natural History Society was organized. Fortnightly meetings were held in the class room of the laboratory until April I 3, I900, when the chapter moved into a new lecture room, 447 Crafts st., West Newton, which had been finished and furnished through the efforts of the members;

In the fall of 1900 , upon the solicitation of members of the chapter the collections of the original Society, gifts of its members and others, were turned over to the chapter, a room having been prepared for their reception. 
These collections, augmented by others given by members of the chapter, have been carefully catalogued, and are now ready to be loaned to teachers and others who are either members of the chapter, or who have acquired the right of access to the collection (see Rules and Regulations).

In order to assist teachers and others who are beginning nature work, accounts of the groups to which given specimens belong are printed, in many cases illustrated with wood cuts.

Although a record has been carefully kept of the donors of specimens, it has not been thought advisable to print the names of such with the names of specimens in the catalogue. Any information upon this subject or any other appertaining to the collections will be cheerfully given to those who desire it by $\mathrm{Mr}$ Walter Gerritson, curator of the museum.

Mention is herewith made of the principal donors of specimens to the original collection:- Dr. J. S. Frisbie, a large and valuable collection of minerals, especially of beryl and quartz, also fossils, etc. ; Mr. Jesse Fewkes, curator of the original society, a fine lot of minerals, rocks, woods, Indian relics etc.; large and valuable collections of minerals, by Messrs. W C. Bates, E. C. Fearing, S. I. Fearing, J. C, Park, F. L. Ordway, R. B. Brown, Geo. Leonard, W. J. Johnson, and Prof S. E. Warren. Corals by Mr. S. A. D. Sheppard.

To the Maynard Chapter; Miss Mary Linder minerals, shells etc., Fossils from Lake Champlain by Miss Myra I. Billings, from Mrs Bracket a fine collection of nests and eggs gathered by her husband, the late Foster $\mathbf{H}$. Bracket, of Dorchester; Messrs L. H. Avery and L. H. Wetherell, bird's nests; Messrs Gerritson and Maynard, miscellaneous.

The chapter solicits the donation of such specimens and books as will be of value to students in all branches of nature study.

Julia S. Doane, C. J. Maynard, Lillian A. Young. 


\section{Catalogue of Birds,}

\section{INTRODUCTORY.}

Birds are a highly specialized class of vertebrates, differing greatly from any other living animals, but showing an affinity through fossil forms (Archaeopteryx, Hesperornis, etc.) to the class Reptiles; both classes undoubtedly having had a common ancestor.

For convenience in study birds are divided into groups which are more or less natural; but it must always be borne in mind that each group either now intergrades with some other group, or groups, or has done so in the past, for all birds were derived from a common stock. Changes in structure, form, color, etc. have been brought about by the changed conditions under which the birds have lived and as conditions are now constantly changing, we may expect to find some species now continuing to change.

In studying the classification of birds we find that they constitute a Class among vertebrates. The next lowest division is Order. Under Order we find in regular sequence; Family, Genus, Species, Sub-species and Individual, for it must always be kept in mind that no two birds, even among the same species, are exactly alike. Each living bird is a separate organism, a conscious, reasoning being, differing in some respects from any other organism, an individual bird.

In this variation of individuals we find the key note that vibrates through the evolution of living forms from the lowest to the highest.

In studying any class of animals it becomes necessary for us to acquire, in a great measure a separate vocabulary of names for the various parts of the animal. For example we do not call the fore limb of a bird an arm as we do in human beings, or a front leg as in a sheep, or a fin as in a fish, although it may be homologous to all three, but a wing. The function of the fore limb in all the animals mentioned is different, hence the reason for applying separate names to each.

When the function of a part is the same in different animals, the same name is usually applied to it in all classes of animals. For example all the animals mentioned, and many others besides, have a heart and stomach, both of which have practically the same function in all species possessing them.

It is thus best in beginning the study of any group of animals to learn the names which have been applied to their different parts. A careful study of the diagram given on the following page will greatly aid students in acquiring the names of the most important parts of a bird. 


\section{CATALOGUE.}

Ordir. Sincing Percilers. Oscines. Birds of this order may be known by three characters:- 1 , hind toe on a level with the three anterior toes

Fig. 1.

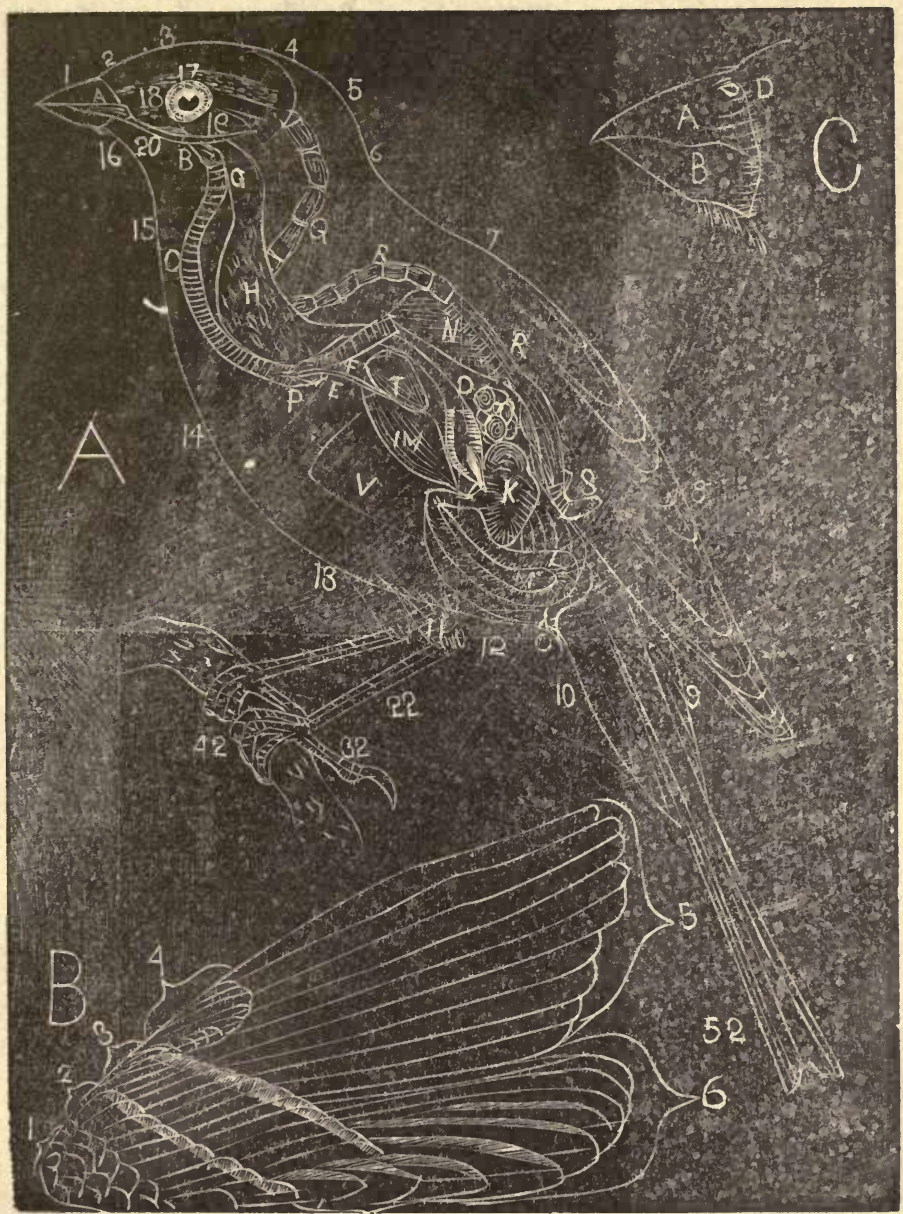

Diagram and Ideal Section of Chipping Sparrow.

A. External Parts: 1, Bill. 2, Forehead. 3, Crown. 4, Occiput. 5, Nape, 6, Ilind neck. 7, Back. 8, Wing. 9, U pper tail covarts. 10. Under tail cojerts. 11, Tibia. 13, Ajdomen, 13, Belly. 14, Breast. 15, Throat. 16, Chin. 17, Superel]iary region. 18, Lores, 19, Ear coverts. 20, Maxillary. 22, Tarsus. 32, Hind toe. 42, Front toes. 52, Tail.

Internal Parts. A, Tongue B, Larynx. P, Syrinx. C, Windpipe. F, Sterno tracheal. F, Bronchial tube. GG, Gullet. $\mathbf{H}$, Crop. K, Stomach. J, Proventriculus, I, Duodenum. W, Pancreas. O, Vent. D, Ovaries, Q, Vertekrae of neck. R, Vertebrae of back. S, Tail bones. 2 , Heart. N. Lungs. V, Keel. I M, Liver.

B. Wing of Chipping Sparrow. 1, Lesser coverts. 2, Middle coverts. 3, Greater coverts. 4, Spurious wing. 5, Primaries. 6, Secondaries.

C. Bill of Cardinal Crosbeak. A, Ufper. B. Iower, mardib?e. D, Nostri?s. 
( see Fig 2):2, the scales on the back prrtion of the tarsus at the point of jointure form a sharp ridge (see Fig. 3, also under head of next order), exception to this rule being the Horned Larks, which see; 3, there are five or six pairs of

Fig. 2.

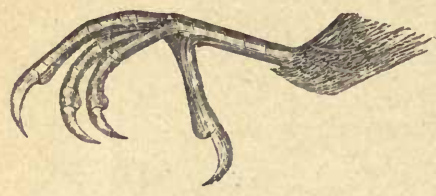

Foot of Purple Martin
Fig. 3.

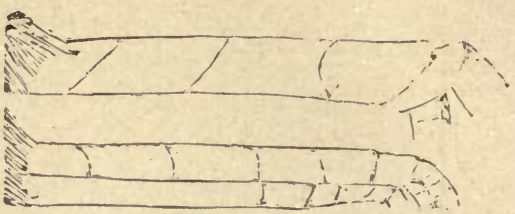

Upper figure, tarsus of Kingbird ; luwer, of Pine Grosbeak ; both enlarged.

m.32les (thus including the sterno-tracheals) which govern the two vibrating membranes of the broncho-tracheal syrinx, and the sterno-tracheals have their orivin on the windpipe below the brencho-tracheals, and are thus not a continuaticn of the lorg trachcals (see Figs. 4 and 5 ).

Fig. 4.

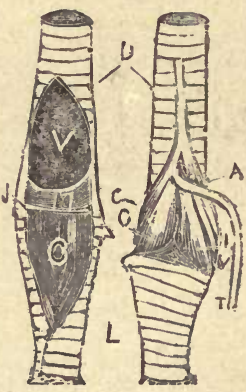

Syrinx of typical Percher. U, Windpipe. CA, Bronco-tracheals. O L V, Bronchials. T, Sterno-tricheal. L, Lronchial tubes. O, Tympaniform membrane. J, Transverse bcne. M, Semiluna membrane. V, Interiur of Windpipe.

Sparrows, Finches, Grosbeaks, Etc., all constitute one family ; the largest and in some ways the most important that we have in New England. In general form members of this family are quite robust, but vary somewhat in this rexpest. The most prominent feature by which they can be rccognized is the comparatively short, thick, conical bill, which is deeper at its base than onehalf its length ( see Fig. 6). There are also nine primaries or flight feathers ( see Fig: 8 on page 10). Internally the gullet is more or less developed into a crup for the storage of food, and the stomach walls are thick for digesting hard seeds; the intestines are quite long, but the coecal appendages are short and functionless (see Fig. 7). Most members of this family sing well, and thus we find a fairly well developed singing apparatus ( see Figs. 4 and 5 and read accompanying explanation). 
GeyUs. True Sparrows. Spizella. Rather slender birds with slightly forked tails. 'Top of head, reddish; unstreaked in adults of our species. No streaks below in adults, and no prominent white markings on tail. Sexes, similar.

\section{FIG、 5 .}

A

B

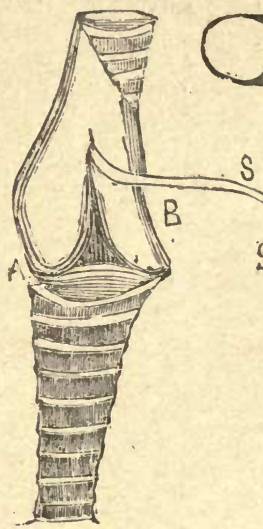

C

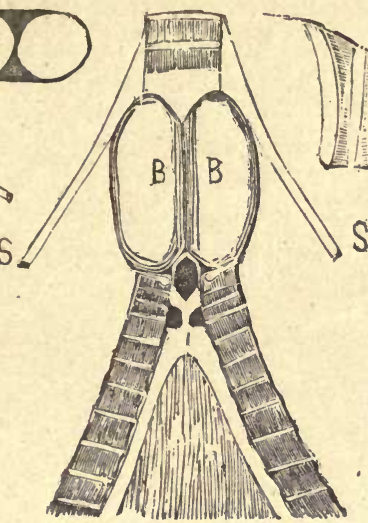

D

Vocal Oroans of Evening Grosbeak. A, transverse bone ; B, portion of windpipe ; C, side view of syrinx and bronchial tube;D. front view of same; E, X-shaped muscle; F, inner side of bronchial tube; А в, broncialis muscles; s, sterno-tracheals; v, vibrating membrane. All enlargej.

1700-2 Chipping Sparrow, adult. Dark line through eye; bill, dark. 1703-4 do do young, streaked on crown.

1705-6 Field Sparrow. No line through eye ; bill, red.

1707-12 Tree Sparrow. Bill, yellow at base beneath; spot on breast.

FIG. 6 .

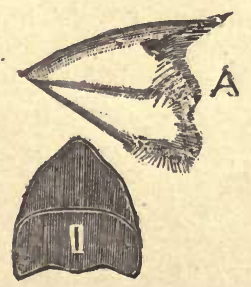

Bill of Rose-breasted Grosbeak ; A, side view ; I, section through base.

Genus. Zone-throated Sparrows. Zonotrachia. Wings rather short; tail rounded; top of head conspicuously marked with black and white.

1713-16 White-throaled Sparrow. Yellow spot in front of eye; throat abruptly white.

1717 White-crowned Sparrow. Throat not abruptly white; no yellow in front of eye. 
Genus. Marsh Sparrows. Ammodramus. Slender birds, with slender bills and with the tail feathers sharpened at tips.

1718-22 Sharp-tailed Sparrow. Prevailing color buff.

1723-24 Sea-side Sparrow. Prevailing color gray.

Genus. Yellow-shouldered Sparrows. Coturnieulus. Small sparrows with short, rounded wings, sharpened tail feathers, and buff colors.

1725-26 Grasshopper Sparrow. Yellow in front of eye, no streaks below.

1727 Henslow's Sparrow. No yellow in front of eye, but streaks below.

Genus. Grass Sparrows. Passerculus. Rather slender birds streaked abore and below, yellow line over eye, tertiaries as long as the secondaries, no white on tail.

Fig. 7 .

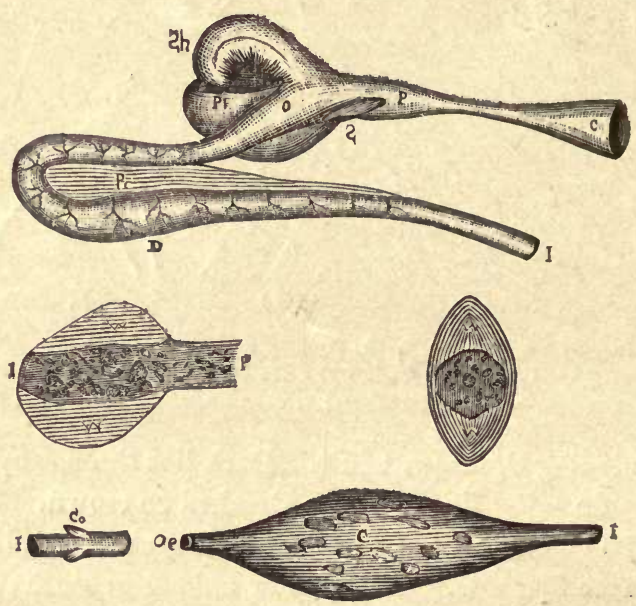

Digestive Organs of English Sparrow. c, gullet; $\mathrm{P}$, proventriculus ; $\mathrm{s}$, spleen; sh, stomach; $\mathrm{P}$, heginning of intestines; $D$, duodenum: P, pancreas; $I$, intestine ; I $P$, lining membrane of stomacls (longitudinal section, transverse section to right) ; w w, walls of stomach in both sections; c, crop ; o, coeca.

1728-32 Savannah Sparrow. Rather dark in color, size small.

Genus. Bay-winged Sparrow. Poocetes. Stouter birds than in the last genus, the tail is longer, the shoulders bay and the outer tail feathers are marked with white; tertiaries as long as secondaries.

1733-36 Vesper Sparrow. General tone of color, gray.

Genus. Longspurs. Calcarius. Birds over six inches long, slender with long wings, and hind toe nail longer than its toe.

1737 Lapland Longspur. Throat and breast, black.

Genus. Snowflakes. Plectrophenax. Wings very long and pointed, colors black and white.

1738 Snow Bunting. Winter dress, colors obscured by reddish, illustrating protective coloration.

Genus. Goldfinches. Spinus. Small birds less than seren inches long, 
with the pointed wings longer than the rather deeply forked tail. Two species.

1758 American Goldfinch, summer plumage.

$1759 \quad 66 \quad 66 \quad$ winter dress.

1759a Pine Siskin. Streaked above and below.

Genus. Red-polls. Acanthus. Size of last genus; bill very short ; wings long; tail forked; streaks on body above and below ; crown, crimson.

1760 Lesser Red-poll. Adult, crimson below, 1761-4 Females and young.

Fig. 8 .

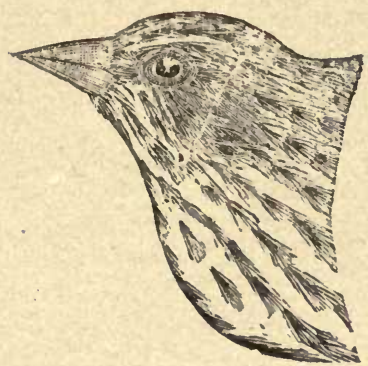

Pine Siskin.
Fig. 9.

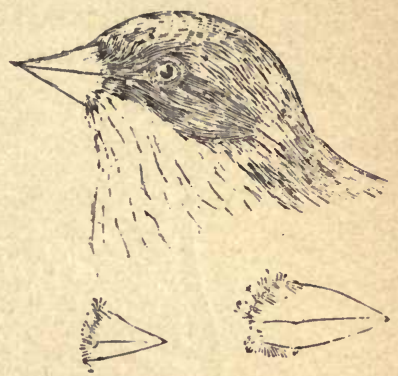

Lesser Redpoll; bills of Hoary alad Holboll's,

Genus. Crossbills. Loxiav Tips of both mandibles of bill elongated and crossed; wings long; tail forked.

1765-65 Red Ciossbill male, 1ed throughout. 1767-8, female, greenish.

1769-70 White-winged Crossbill. Male, rosy, wing bands white.

$1771-72$ " 6 \%

Fig. 10 .

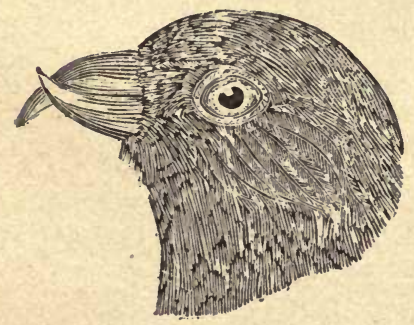

Red Crossbill.
Fig. 11 .

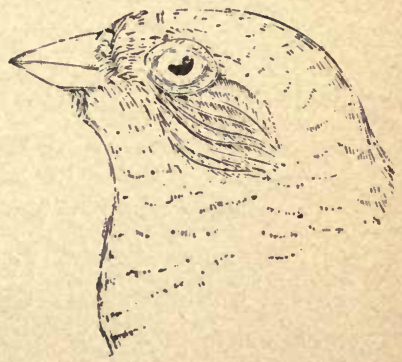

Snow Bunting.

Genus. Rosy Finches. Carpodicus. Bill, thick ; wings long; tail deeply forked; head, sub-crested.

1773 Purple Finch. Male, crimson throughout.

1774. " " Female, gray, streaked.

Genus. Pine Grosbeaks. Pinecola. Large birds, eight inches long; bill, short and thick; wings, long; tail, deeply forked. 
1775 Pine Grosbeak.

Genus. Snowbirds. Junco. Small, less than seven inches long; slatygray above; outer tail feathers, conspicuously marked with white.

1776-78 Snowbird, male, Very dark above.

1779-81 “ " female, duller.

1782 6 nestling, streaked below.

Fig. 12.

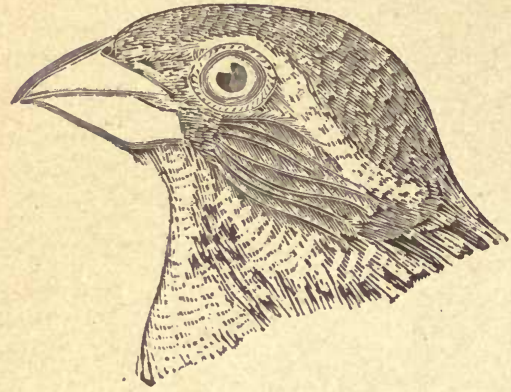

Female Rcse-treasted Grosbeak.
Fig. 13. .

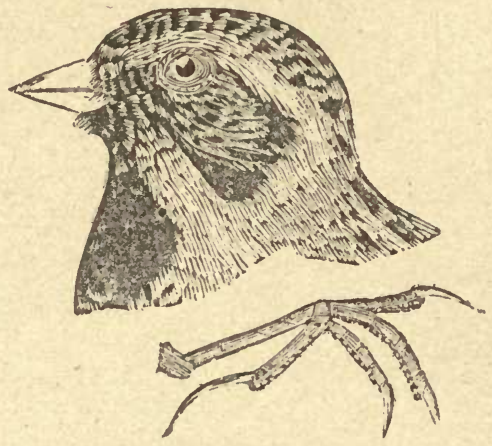

Lapland Longsp::r.

Genus. Song Sparrows. Melospiza. Size of last genus; reddish-brown above streaked with dusky; wings, short; tail, long and rounded.

1783-87 Song Sparrow, conspicuously streaked below; spot on breast.

1788-89 6 6 nestling, more finely streaked.

1790-92 Swamp Sparrow, streakings beneath, indistinct.

Fig. 14.

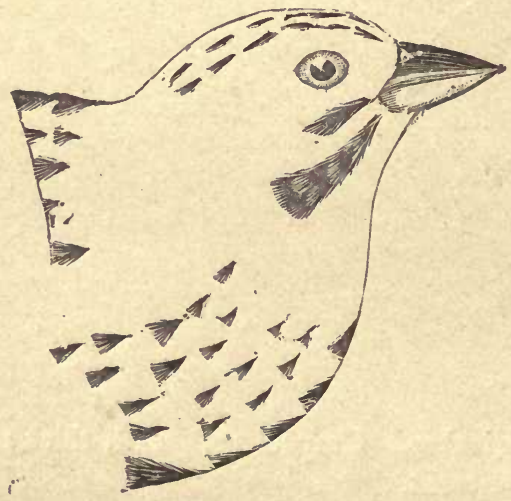

Song Sparrow.

Genus. Rufous Sparrows. Passerella. Large; prevailing color rufous, spotted with rufous beneath. 
1794 Fox Sparrow.

Genus. Ground Buntings. Pipilo. Large, over eight inches long; wings, short; tail, long, rounded and conspicuously marked with white.

\section{Fig. 15}

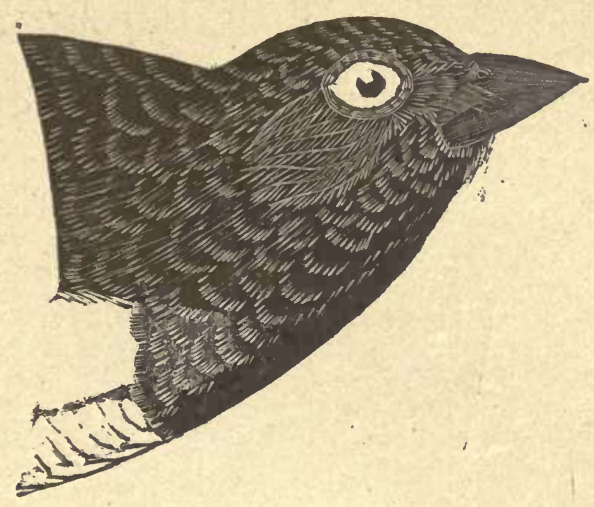

Head of Towhee.

1795-96 Towhee, Male, black above.

1797-98 “ Female, brown above.

Genus. Cardinals. Cardinalis. Large, over eight inches long, with thick bills, crested heads and bright colors.

1799-1801 Cardinal Grosbeak. Males, colors bright.

\section{2-3 " " Females, colors duller.}

Genus. Song Grosbeaks. Habia. Large, about eight inches long, with thick, heavy bill. Males black, white, and rose; females, duller.

Fig. 16.

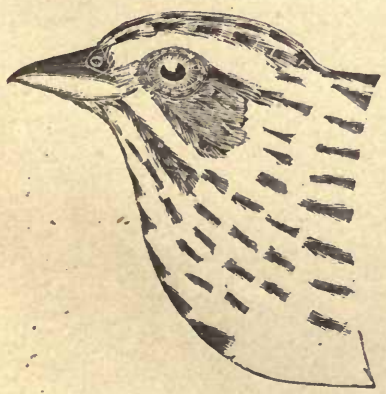

Savanna Sparrow.
Fig. 17.

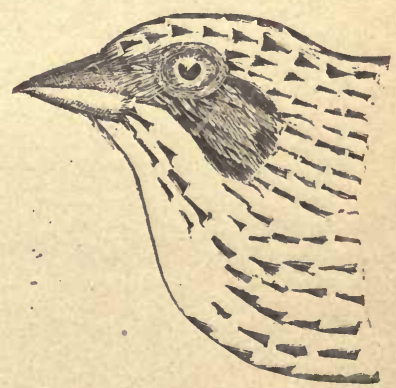

Vesper Sparrow.

1804 Rose-breasted Grosbeak, Male.
1805 “
“ Female.

Genus. House Sparrow. Passer. Stout, with thick bills, long, pointed wings and forked tails. 
1806 English Sparrow. Male.

1807 " "

Family. Orioles, Starlings, Blackbirds ete. Icteridae. Bill but slightly curved; lower mandible more or less swollen at the base, unnotched; primaries, nine; csatains a variety of birds of diverse characters; see Genera.

Fig. 18.

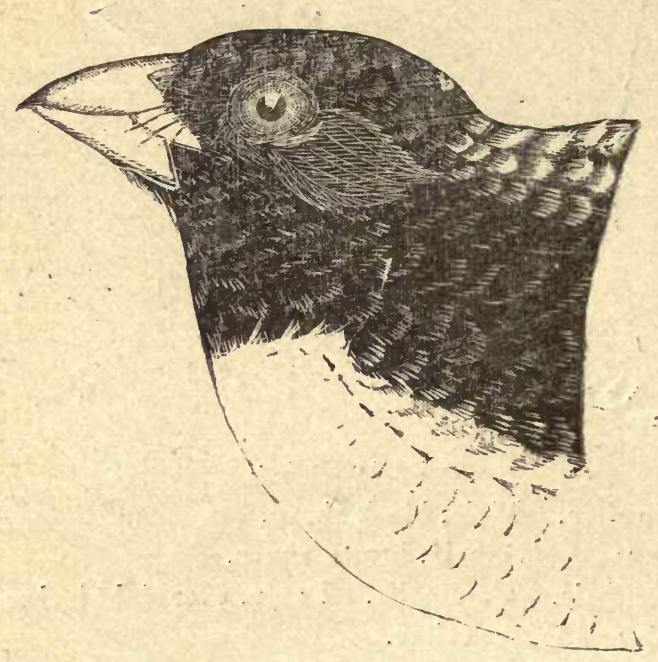

Ma'e Rose-bressted Grosbeak.

Genus. Rice Buntings. Dolichonyx. Bill thick and conical, shcrter than the head : wings long; tail rounded with the feathers acuminate.

1808 Bobolink, Male, black and yellowish wlite.

$1802 \quad \cdots \quad$ Female, yellowish buff.

Genus. Parasitical llackbirds. Molothrus. Bill thick and conical : wingss rather long ; tail rounded ; feathers not acuminate.

1810 Cowbird. Male, hlack, head coffee-colored.

1811 " $\quad$ Female, brownish slate throughout.

(jenus. Redwings. Agelaeus.

1812-16 Red winged Blackbird. Males, adults, Black, red shouldcrs.

1817.18 " $\quad$ " " $\quad$ " Young, more or less mottled with brown.

1819-22 " " " " Females, brown streaked with whitish.

Genus. Meadowlarks. Sturnella. Bill pointed, broad at tip : wings long: tail short: feet large.

1823-27 Meadowlark. Males, bright yellow beneath, crescent on brea: $t$ black.

1828-30 Meadowlark. Females, duller, black rusty.

Genus. Rusty Blackbirds. Scolecophagus. Bill slender, slightly curred: wings long; tail slightly rounded. 
1831. Rusty Blaskbird. Spring Male. Black throughout, no red.
1832. “ ".
Ma e in Autumn, Black rusty.
1833.
6 "6
Female. Slaty brown throughuut.

Genus. Boat $t$ tiled Blackbirds. Quiscalus. Bill stout, about as long as head, sli shtly curved: wings rather short ; tail long and graduated.

1s54. B.ouzed Giackle. Lines of cemarkation between head and back s'arply defined.

183 j. Purple Grackle. Line of demarkation between head and back not s harply defined.

1836-37. Florida Grackle. Males, more iridescent than the last two species.

1838.

“ Female, smaller and duller.

1839-40. Boat-tailed Grackles. Male, large, more uniform in color. Southern States.

1841-43.

$\because$

Female, reddish brown throughout.

Family, Crows and Jays. Corvidae. Bill stout, not swollen at base; nostrils covered with projecting bristles.

Genus. Crows. Corvus. Wings long; tail rounded; color generally black.

1844. Common Crow. Mildle toe shorter than tarsus.

1845-46. Fish Ciow. Size smalier ; mid l. toe longer than tarsas. New Yurk Southward.

Genus. The Blue Jays. Cyanurus. Bill stout and conical. . Wings and tail rather long. Prevailing color bluish. Head crested.

1847-48. Blue Jay. Black markings on side of head and breast.

Genus. Bush Jays. Cyanocita. Head not crested. Wings short and tail long.

1849-50 Florida Jays. No distinct black markings on side of head or below.

Family. Tanagers. Tanagridae. Bill rather large and conical; under mandidle more or less swollen at base; wings and tail of medium length.

Genus. Tooth-billed Tanagers. Pyranga. Cutting edge of upper mandible provided with a prominent tcoth.

1851. Sca let Tanager. Male, scarlet, wings and tail black.

1852. " " * Female, greenish throughout.

Family. American Warblers. Miniotiltidae. Small birds, less than six inches long, with slenter bills and nine primaries.

Genus. Mniotilta. Creeping Warblers. Bill, long and curved; wings, folding beyond the middle of tail ; feet, large.

1853-55. Black and Whit Warbler. Colors, black and white, crown divided by a white line.

1855-59. Yellow-rumped Warbler. Yellow spot on top of head on rump and sides.

1860. Magnolia Warbler. Black and yellow; white spots near middle of tail. 
1861-61 Pine Warbler. Male, greanish-yellow; no black markings.

1865-66 Pine Warbler. Female, duller.

1867 Black-polled Warbler. Male, adult in spring, black and white no dividing line on crown.

1868-70 Black-polled Warbler. Female and autumnal birds, greenish streaked beneath.

1871 Prairie Warbler. Beneath, yellow, streaked with black on sides and sides of head; back with spots of chestnut.

1872-73 Yellow Red-poll. Top of head, chestnut.

Genus. Golden Warblers. Prevailing color, yellow, no wing bands, nor tail spots.

1874 Yellow Warbler. Male, reddish streakings distinct.

$1 \varepsilon 75$ " " $\quad$ Female, duller.

Genus. Little Warblers. Small; wing bands and tail spots, present; greenish-yellow spot in middle of back.

1876 Blue Yellow-backed Warbler. Yellow and white beneath, burnt-sienna on upper breast.

Genus. Ground Warblers. Wings short; yellow on throat.

1877-78 Maryland Yellow-throat. Male, black mask on face.

1879-80 " " $\quad$ Female, duller; no mask.

Genus. Painted Warblers. Black with spot of salmon on wing and side.

1881 Redstart. Male, black above and on head.

1882 " Female, black replaced by brownish, salmon and yellow.

Family. Pipits. Bill, slender ; wings, long ; tertiaries, elongated.

Genus. Titlarks. Slender birds with white markings on tail.

1883-84 Titlark. Distinctly streaked beneath.

Family. Kinglets. Small ; bill short; nostrils concealed by feathers. Wings distinctly banded.

Genus. Golden-crowned Kinglet. Center of crown, golden, with colored feathers.

1885 Golden-crowned Kinglet. Male, center of crown, golden.

1886 " " " Female, center of crown, yellow,

1887 Ruby-crowned Kinglet. Male, center of crown, ruby.

1888 " " " Female, no bright color on crown.

Family. Thrushes. Wings, moderately long; bill, rather slender; tarsus vith a single scale (booted).

Genus. Large Thrushes. Size, large; no streaks below in the young of ur species.

1889-90 American Robiu. Male adult, bill quite yellow.

1891 " " " Female, duller, bill, darker.

Genus. Spotted Thrasher. Size smaller, spotted below. 
1892. Hermit Thrush.

Family. Rock Inhabilers. Bill, shorter, wings long and pointed ; feet, small.

Genus. Bluebirds. Mostly blue above.

1893-94. Bluehird. 1S95-96. Same, females.

Family. Wrens. Wings, short; bill, short and more curved.

1895. House Wren. Size, small; tail distinctly banded.

1896. Brown Thrasher, larger, tail long.

1897. Catbird. Color, nearly uniform slaty-gray.

Family. Titmice. Wings, short; tail, long; plumage, fluffy.

1898-99. Chickadee. Top of head and throat, black.

Family. Nuthatches. Tail, short; wings, long; bill, straight.

1900. White-bellied Nuthatch. curved.

Family. Tree Crecpers. Tail, long with each feather pointed; bill,

1901. Brown Creeper. Brown, streaked with lighter.

Family. Crows and Jays. Bill, stout and conical; nostrils, concealed by feathers.

1902. Blue Jay. Wings, short; tail, long.

1903. Fish Crow. Legs, long.

Family. Vireos. Small birds with rather stout bills.

1904. Red-eyed Vireo. Dark line through eye.

1905. White Vireo. Yellow about eye.

Family. Waxwings. Wings, long with shaft of secondaries often expanded at termination.

1906. Cedar Bird. No white on wing.

Family. Swallows. Wings, long; bill, short; gape, wide.

1907. Tree Swallow. Pure white beneath.

Order. Songless Perchers. Syrinx without complicated singing muscles Tarsus without two sets of scales (see Singing Perchers, page 7). This order in America is represented by Flycatchers.

1908. Kingbird. Top of head with concealed orange spot.

1909. Phoebe. Olive brown above; whitish beneath.

Order. Woodpeckers. Wings, long; tail, short and with stiffened, point ed feathers. Toes, two in front and $t$ wo behind.

1910. Downy Woodpecker. Outer tail feathers spotted.

1911. Flicker. Bill, somewhat curved.

Order. Cuckoos. Tail, long and graduated. Toes, two in front and two behind.

1912. Black-billed Cuckoo. White spots on tail not prominent; no yellow on bill.

Order. Kingfishers. Bill long; wings long: tail short.

1913. Belted Kingfisher, male, with bluish belt.

1914. " " female, with a second belt of reddish brown.

Other birds will be added to the collection as fast as thev can be purchased when supplementary catalogues will be issued. 


\section{Catalogue of Minerals.}

QUARTz. Pure silica; an oxide of silicon, ccmposed of about 47 parts of si icon and 53 of oxygen. The element silicon never occurs in a natural condition uncombined with oxygen. When seperated artificially it appcas in tro conditions; amorphous (without form) as a black powder, and crystalline as brilliant, black scales. Oxygen, the most abundant element in nature, also noted for the readiuess with which it combines with nearly all other elements, when pure, in a natusal condition is a gas. Quartz is an exceedingly abundant mineral, perfectly transparent when pure, crystallizing in six sicled prisms. It is laad c nough to scratch glass readily and breahs with a curred cr sbell-like (cl.cncloidal) fracture, and it is difficult to make it break with a truecleavage. It feels rather grez. sy to the touch.

Fig. 37.

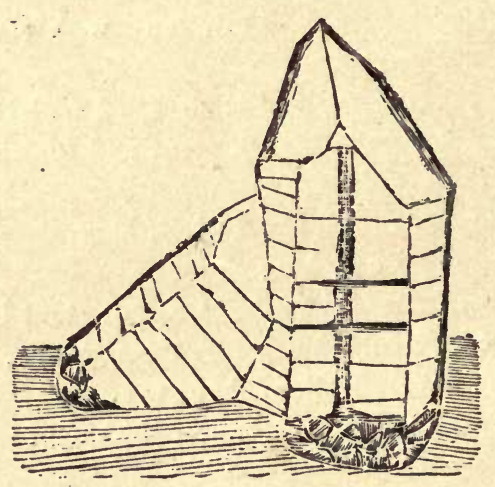

Quartz Crystais.

Quartz com'ines quite readily chemically with other minerals or elements, and often crystallizes thus combined; with iron, producing milky or smoky quartz; with titanic acid, rose quartz; with manganese, amethrstine quartz, or amethyst.

- Mechanically quartz is broken into fragments by ice and frost action; these fragments are worn by water first into pebbles, then into sand, which, under certain conditions, becomes cemented together to form sardstone, which under other conditions may disintegrate back again into sand.

Organically, quartz which has been taken into solution by water is absorbed hy plants, plaint-a aimals, and animals, notable eximple $s$ of which a re the diatomes, radiolaria, and sponges. The remains of these form flint, which through age becomes novaculite, chert, and hornstone. From I lant life it is returned to the soil and under favorable conditions becoming agate, $x=d$ chalcedony.

Under pressure, forming rock masses through c1o-s led crystallization, or in con bination with one or all of the following minerals, feldspar, hornblende, mica forming different kinds of granitic rocks, which through age, pressure, and possibly partial fusion, become tae diabases. 
Fused, more or less highly, and in combination with feldspar and other minerals, producing quartzite, feldsite, jasperite, obsidian or volcanic glass, one form of which is pumice, which may be ground into ashes or volcanic dust.

From being held in solution in water quartz often fills rock cavities and fissures, entering them from above, and thus may enclose other minerals like pyrite, garnets, epidote, etc., or metals like copper and gold.

From being held in solution quartz also often fills the cavities in rocks once occupied by the crystals of other minerals but which have been dissolved away, leaving a mould of their form, and then the quartz assumes a crystalline form not its own, but that of the mineral of which it took the place. This change may have iaken place gradually as the dissolving mineral disappeared. In a like manner quartz sometimes takes the place of decaying wood, shells of mollusks, cora], or other organic structures, often reproducing their forms with perfect exactness; th is exact reproduction is particularly noticeable in the case of wood in which the cells and grain are to be seen. Such reproductions of organic structures are called, rather incorrectly, petrifactions, but are more correctly termed pseudomorphs, which means false forms. It is usual to designate the form assumed by the quartz as quartz pseudomorph after the crystal, of organic structure. Thus, for example, we may find quartz pseudomorph after pyrite, calcite, etc., or quartz pseudomorph after wood or coral, etc.

In the arts pure crystalline quartz has been used as lenses for eyeglasses, microscopes, etc., and also in this form, or when colored in the chemical series or as agates, in jewelry. Primitive man used quartz in its various forms, pure and impure, as implements and weapons. In both ancient and modern art it enters largely into the composition of glass and from some of its combinations, as in the sandstones and granite, are produced excellent building stones. Quartz in many. of its forms is well illustrated in the collection.

Those desiring particular varieties of quartz like Gold-rearing, Iron-stained, Drusy, Smoky, Amethyst, Massive, Crystaline, etc., will please designate the variety they require

Quartz Amethyst 252456.

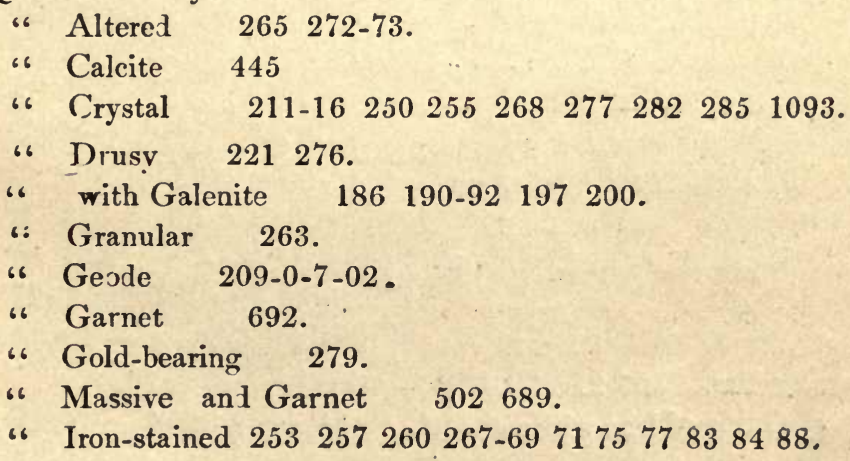


Quartz and Jasper 237

Quartz Massive 223-34 40-42-43-45-48-51-54-62-64 502.

Quartz and Mica 246-59 497-500.

Quartz Mammaliferous 214-38-94 336-38.

Quartz with Opal 659.

Quartz and Peacock Copper 877.

Rose 235-39-70-78.

Smoky 266-81 12681536.

Galenite and Oxidizing Pyrites

652-58.

Qiartz "249404 1000-01-06-09-13 1548.

Q11artzite 289-90 $805 \quad 1003-04-05-11-64-931205$.

Gold-bearing Quartzite 417.

See also flint, chalcedony, agate, quartzite and jasper

Agate. A kind of quartz formed by concretion. 308-10 314320332 101712251232.

Beryl. Silicate of Alumina combined with glaucina and very hard. $759-$ 66 $768-7 \tau$.

Cinnabar. A sulphate of quicksilver from an earthy form of which the Indians obtained vermillion. 51-j3d 1538-39.

Fossils. $\quad 581 \quad 590 \quad 921 \quad 925-29 \quad 193-32 \quad 934-40 \quad 943-54 \quad 956-48 \quad 1075-82$ 1090-92 $1089123412761516-1744945145359156757$.

Calcite and Copper. $2222 \mathrm{a} 23$.

Peacock C.spper. A sulphate of Copper. 152.

Calcite Crystals. 4551023.

Calcite. Carbonate of lime. 446-47 449703 715-18 1022.

Copper Pyrites. Sulphate of copper. 35364446 50b, c, d, e, f 135.

Copper Mat. A Copper Ore. 43.

Copper, Sulphate of $36 \mathrm{a} b, \mathrm{c}$

Copper, Native Copper is one of the few minerals that occurs as a metal in Nature. 1-23 2la, b, c 29408631043.

Copper Ore. 363838 a 49501270.

Copper, Silicate of 394042 .

Feldspar. A silicate of Alumina, containing an alkaline base and enters largely into the composition of rocks like granites etc. $\quad 419-42663985873$.

Feldsite. Feldspar containing impurities largely quartz. 443-44804812 847-48 884-85 104011047 22-29 737-39.

Flint. See quartz $309311-12$.

Galenite Sulph ite of Lead. An imported ore of this metal '160-68 170_ 84 186-96198 8711039.

Gold Ore 134 47-48 505 1524 .

Gold-bearing Ore. 126-2.

Hematite. Oxide of Iron without water. $92-97379$. 
Hematite, Slaty 554 586-87.

Iron Pyrites. Sulphate of Iron. 545665 b c, d, e, f $64 a, b 909$ I 6601074 I I 50 a 65.

Iron Ore. $105^{-1} 8$ I58 $34^{6} 353367641872$.

Limonite. Oxide of Iron containing water. $79-8082-88$ I59 708 I046 I257 I 52 I

Magnetite. An oxide of Iron without water. 68-77a 664.

Malachite. Carbonate of Copper. 27 28-30 $37 \mathrm{a} \mathrm{b} \mathrm{c.}$

ica. $\Lambda$ silicate of Allumina, 457-77 478496.

Mica and Quartz 497-500

Mica Schist. Largely composed of pulverized Mica. 5or $563615620624-32662$ 63 813 1050-55 1073 I $136-37$ I 202.

Lead Ore. Galenite. Sulphate of Lead. I60-65 I 85 .

Novaculite. See Quartz. 32I -31 4I 4-15 730-39 749-850-61 $35^{8}$ I I53.

Antimony. 1090-91.

Actinolite. 360-61 3661239.

" and Calcite 342359.

“ Fibrous 367-71.

Amphilole, Hornblende 649-5 1 .

Alum. 755 .

Amygdaloid. 545 874-76 $1057-59$ I 102 I Ig0 I 263 I I 80 I I 88-89.

Borax. $75^{6}$.

Baculite. 930933941 .

Bronzite. 2251 .

Chromate of Iron. Iron. Iron and Chromium.

Calcite in Anthracite. 667.

Coal. 665-66.

“ Brown or Lignite. I026.

“ Cannel 668-70.

“ Bituminous 671-738 19 .

“Shale 1027-29.

“ Fossiliferons Shaly 674-84.

Coke. 686.

Conglomerate. I 166-87 i 196,

Chalcedony. 334334337 .

Chalcopyrite. Sulphate of Copper. $50 \mathrm{i} 50 \mathrm{j}$.

Copper Pyrites with Silver. I 35 I 38.

“ and Silver. 1384748.

“ Ore and Pyrites. 139.

Carbonate of Lead. 20r.

Calcite. Shell sand. I215-15.

Calcareous Formation. 453.

“Tufa. 454.

Crinoid Stones. 1293.

Calcite and Chlorite. 803 .

Clay. $747-48$.

“ Indurated 740-42 745-46 805-6.

“ Hydrocarbonate $72 \mathrm{I}$.

“Stone 824-27 879-8I

“Slate 604-7 6i1 743-44.

Cuprite and Malachite. 3I

Chalcochite. 
Cortellite Co sper Pyrites and Silver. 46

Copp $\lrcorner$ r Chalcopyrite. $50 a$

Crystal of Iron Pyrites. 632.

Carn zlian Agate. 333.

Diabase. I 106 I I 20-22 I I 33-34 I I 24-28 I I 52 I I 58-59 I I 98 I 237-38.

Dolomite. 1297.

Divoite. I160-9I I207-10.

Graphite. $828-75893$ I ror 1303 .

Gold-bearing Slate. 882 .

Gneiss. II 39 .

Gneissoid Rock, I 302

Gypsum. Sulphate of lime. 781-98800.

Garnet. I 243 .

Gold and Silier Orcs. I 24 131-32 I 43 149-59,

Galenite, Silver and Gold. 182.

Galentine and Silver. I66-68 I 70-73 I 75-78 ISI-82 I95.

Gold, Silver, and Pyrites. 128 r 30.

" " "Galentine. 184 .

" and Galentine. 179.

Galenite and Tin. 180 .

Galenite Crystal.

“ and Iron. 196.

Garnet. Feldspar and Schist. 691.

Granite. Of varied composition. 1031-35 1231-32 1235 1107-16 1 1123 $11129-35$

II 5j-5j I055-72 II 97 I 199 I 522 I 567 .

Granite, Schistose. I305.

Hormblende. $362-63$.

“ Schist. $380772-77$.

“ $\quad$ imphibole. 649-5x.

Habyrite. 808-10.

Limestone with Gold. 1547.

“ 704-6 7 II I-13 1024-25 1085-88 1201 I 206 I216 I 266.

Leprodite. Hornblende Crystals. 814 8I6.

Lignite. (See Brown Coal). 685 I065 I 275.

Lava. 986-99 905-11 1045 I 273.

Marble. Equals Calcite, which see. 695698702.

Manganite. 153 .

Manganese. 1126-62.

Slate with Dendrite. Hardened Clay. 543544 294-99 606.

" " Copper. 593.

" " Fossils. 603.

" “ Andalusite. 602 .

“ “ Fossil ferns. 592608610.

“ " " Brachiopods. 591.

" " Footprints, probably reptiles or batrachians, 583 .

“ “ Fossil fish bone. 585.

“ “ Fossil crinoids. 590.

“. " Trilobite. 574584 .

“ "Hornblende crystals. 600601 . 

. 
U.C. BERKELEY LIBRARIES

C026059956 


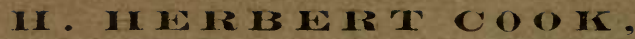

46 PARSONS STREET, WEST NEWTON.

HEALTH BY NATURAL METHODS.

Ralston Physical Culture, Cultivation of the Chest, Nerve Calisthenics, Special exercises for overcoming chronic maladies, Class and private work.

Standard works by C. J Maynard.

Birds of Eastern North America, $\$ 25.00$

Manual of North American Butterfies, \$1.50

Eggs of North American Birds, \$2.00

The Naturalist's Guide, \$1.25

Contributions to Science, $\$ 5.00$ per vol.

(Three volumes now ready.)

The Bahama Fruit Finch, $\$ 5.00$

Sparrows and Finches of New England, \$I.50

Sponges, (Nature Studies, No. II.) 85 cts.

Warblers of New England (in press)

Parts I to 4 now ready.

\section{ZOOLOGICAL SUPPLIES}

For Schools, Colleges, otc.

LIVING SPECIMENS

FOR AQUARIUMS, ETC

CONSTANTIY ON HAIND.

Send For Our Illustrated Catalogue.

C. J. MA INA RD \& CO.

447 Crafts Street,

West Newton, Mass. 